\title{
A New Aspect of Internationalisation? Specific Challenges and Support Structures for Refugees on Their Way to German Higher Education
}

\author{
Jana Berg
}

\section{Introduction}

In 2015 and 2016, the number of asylum applications spiked in some European countries, including Germany. Many refugees and asylum seekers have high educational aspirations (Brücker et al. 2016), and their level of education determines their chances of integration and success in the host country (Fortin et al. 2016). Therefore, the question of how to integrate refugees and asylum seekers into higher education institutions (HEIs) became increasingly relevant. Supported by the Federal Ministry of Education and Research (BMBF) and the German Academic Exchange Service (DAAD), universities, universities of applied sciences and preparatory colleges started the "Integra"-programs to assist refugees on their way to and through higher education (Fourier et al. 2017).

Based on a system theoretical intersectional perspective, this article works out what first contacts for refugees, members of the international offices and a vice-president at 5 German HEIs of internationalisation identify as specific challenges for refugees and asylum seekers ${ }^{1}$ on their way to German higher education, and then focuses on how German HEIs support them. Concluding, it recommends backing HEIs up financially in order to encourage and help the process of institutionalising supporting structures; and also to target more networking and

\footnotetext{
${ }^{1}$ While it will generally be referred to refugees in this text, technically, some of the prospective students are also asylum seekers, which means they do not have received a refugee status yet (see Columbia n.y.).
}

J. Berg $(\bowtie)$

German Centre for Higher Education Research and Science

Studies (DZHW), Hannover, Germany

e-mail: berg@dzhw.eu

(C) The Author(s) 2018

A. Curaj et al. (eds.), European Higher Education Area: The Impact of Past and Future Policies, https://doi.org/10.1007/978-3-319-77407-7_15 
exchange of information between the HEIs. The article argues for an understanding of refugee students as internationals, as an addition to the HEIs and societies' diversity and as potentially highly skilled students.

\section{Access to Higher Education for International Students, Asylum Seekers and Refugees in Germany}

Regardless of their residential status, refugees can apply to any German higher education institution; as long as they fulfil the general criteria for international applicants, they will be treated as international students (Study In n.y.a). Mostly, that means to hold a university entrance qualification and speak the required language, which in the vast majority of German Bachelor programs is German, on a C1 level.

Study preparation and access to higher education in Germany are central issues for international students: $32 \%$ of international students come to Germany with a high school diploma, while $21 \%$ had previously studied abroad, but had not completed their studies (Apolinarski and Poskowsky 2013, p. 4). International diplomas need to go through a process of recognition before being acknowledged as university entrance qualifications in Germany. The German Act of Recognition, however, is not applicable to school certificates obtained in non-EU countries (Anerkennung in Deutschland n.y.). Therefore, the matriculation offices or international offices of higher education institutions take the decision on their eligibility.

Preparatory courses can be a crucial aspect of access to higher education. Prospective international and refugee students with secondary diplomas that are not recognised as university entrance qualification in Germany have to take an assessment test ("Feststellungsprüfung"). They can enrol in either private or public ${ }^{2}$ preparatory colleges ("Studienkollegs") to study for this test (Studienkollegs.de n. y.). The two-semester courses cover terminology and basic knowledge in the desired academic field. In 2012, $18 \%$ of all international students had to visit a preparatory college (Apolinarski and Poskowsky 2013, p. 5).

While technically, refugees are treated like all international (prospective) students during their application and enrolment, during the phase of study preparations they receive special support in order to deal with their specific situation. For example, the entrance criteria for the preparatory colleges already include advanced knowledge of the German language. Therefore, special classes prepare refugees for the entrance test in order to enrol in the preparatory courses that lead to the assessment test (Studienkolleg Hannover n.y.). Additionally, HEIs started offering courses, for example language and math classes, to support prospective refugee

\footnotetext{
${ }^{2}$ Cost and availability of preparatory colleges depend on the German state and the individual college.
} 
students on their way to higher education (Beigang and von Blumenthal 2016). In 2016, 6806 refugees and asylum seekers took part in courses offered by 135 HEIs and 37 preparatory colleges within the "Integra"-program (Fourier et al. 2017: 12). Due to the time needed to reach the necessary language skills for study preparations, it can be assumed that the number of refugees in preparatory courses is still going to increase. Generally, preparatory colleges and preparatory courses can be seen as important institutions for the internationalisation of German higher education and the support of prospective refugee students.

\section{Challenges and Support for Refugees and Asylum Seekers at German HEIs}

In order to work out specific challenges for refugees on their way to higher education and to compare the support and integration programs at different HEIs, I conducted eight expert interviews (Kruse 2015, p. 166 et seq.; Bogner et al. 2002) at five HEIs in four German states ("Bundesländer"). My interview-partners where first contacts for refugees, members of international offices, one head of an international office and one vice-president for internationalisation. The sample consists of members of five HEIs, two universities of applied sciences and three universities, in four different German states and regions. The HEIs have been sampled based on a regional cluster to cover different areas in Germany and on their support for refugees (existing support and special programs). An additional criterion was to include a university of excellence. ${ }^{3}$ I analysed the interviews and the mission statements for internationalisation as well as the information for refugees offered by the universities' website with content analysis. In the following, an overview of the specific challenges for refugees the interview-partners described will be given, followed by short descriptions of the sampled HEIs and their support for refugees.

\section{Specific Challenges on the Way to Higher Education for Refugees and Asylum Seekers: An Intersectional Approach}

Prospective international students face a variety of challenges in Germany. It can be assumed that, to some extent, refugees face similar difficulties as all international students, amplified by and in addition to hindrances arising from their specific

\footnotetext{
${ }^{3}$ The excellence initiative is a program by German's federal and state's governments to fund and support outstanding programs and institutions at selected universities. In intervals of 7 years, universities have to apply with proposed excellence clusters. Each time, 11 universities will be selected to be of excellence and receive the funding (see BMBF n.y.).
} 
situation. In addition to entrance qualification (Brücker et al. 2016, p. 5) and language, literature on the situation of international students in Germany identifies several issues, for example study culture, finances (Schammann and Younso 2016, pp. 12-13), social isolation, information and support (Ebert and Heublein 2017; Levantino 2016, p. 90), gaps in the educational biography (Ebert and Heublein 2017 , p. 32) and residential status as possible central challenges for access to and success in higher education in Germany (Apolinarski and Poskowsky 2013; Morris-Lange 2017). Trauma (Joyce et al. 2010) and residence obligations for asylum seekers are examples of additional hindrances for (prospective) students with the experience of forced migration.

The situation of refugees can be understood as an intersection of various factors of marginalisation. This means that those factors don't simply coexist or add up but interdepend and influence each other. They cannot be understood independently but have to be considered within their interdependence (see Müller 2011, p. 305). Instead of focussing on set factors like race, class and gender, as it is often done in intersectional approaches (see Müller 2011, p. 302ff.; Weinbach 2008), this article focuses on the factors influencing refugees' integration into HEIs that members of HEIs describe from their perspective, ${ }^{4}$ following Weinbach's (2008) system theoretical approach to Intersectionality. The factors highlighted here are those influencing the inclusion into the HEI as an organisation and cannot be understood as a holistic representation of challenges refugees face within the host society. Some of those factors also apply to national or international students with no experience of forced migration; their specific combination is due to the individual situation - in this case, the specific situation of refugees. It can be assumed that some issues are amplified and others added by the specific situation of refugees. Also, their impact differs. While language and entrance qualification influence the access to higher education directly, others can be crucial hindrances for learning conditions and the general possibility of remaining in higher education. In the following, I will give an overview of several closely connected and interdependent challenges for prospective refugee and asylum-seeking students that were described by HEIs members throughout the interviews.

\footnotetext{
${ }^{4}$ This paper is based on the perspective of members of German HEIs. For an advanced understanding of the situation and needs of refugees, their perspective must be considered. Studies as the WeGe-project (www.wege.dzhw.eu) are working on this task. It can be assumed and some studies show that refugees will have different perspectives on some of those aspects, or even add completely others (see Stevenson and Willott 2007: 675). Harris and Marlowe indicate that staff members do not always "recognise important factors contributing to" (ibid., 2011: 190) refugee students' performance. Examples are aspects of age (Schammann and Younso 2016, p. 28) and gender (Hobsig 2004), which have only been briefly mentioned in the interviews this paper is based on.
} 


\section{Language}

It stands and falls with German language training and finances

(Interview international office member, University E, translated by JB)

Speaking German is a crucial skill and a requirement for applying for German higher education as well as for preparatory colleges. Preparatory colleges usually require German on at least a $\mathrm{B} 1$ level; HEIs often require a $\mathrm{C} 1$ level for inscription and also B1 for preparatory classes. More than one third of all international students describe their German as bad (Morris-Lange 2017, p. 21; Apolinarski and Poskowsky 2013, p. 48). While a total of 54\% of international students' state to have acquired first language skills before coming to Germany. Refugees seem to start with less previous experience. In a study of the Institute for Employment Research (IAB) with 4500 refugees in Germany, 90\% stated to not have had any knowledge of German when entering the country (Brücker et al. 2016, p. 7); there is no statistical information on the selective group of those who plan on studying, but according to the interviews, the level of refugees' German language skills is regularly very low in the beginning. The missing language skills of prospective refugee students in comparison with other foreign students are explained by some interview-partners with the unpredicted nature of their stay in Germany. Since they mostly did not plan to study in Germany, they did not prepare it with language classes.

Another issue is the diverse quality of language classes offered for refugees. Not all of them are accepted by the universities so it has to be certain classes which, on the other hand, are not always accepted by the job centres or the immigration office. This points out another issue: Refugees have to generally consider the rules, requirements and restrictions of several institutions connected to their financial situation and their residential status.

\section{A Multitude of Bureaucratic Requirements}

The life of asylum seekers is highly regulated in Germany. Benefits, accommodation and integration support like language classes or integration courses are connected with official requirements they have to meet. They differ locally by state and on the municipal level, and partly depend directly on the person responsible. Schammann shows exemplarily how the Asylbewerberleistungsgesetzes (AsylbLG), the law that regulates social benefits for refugees in Germany, depends on the interpretation of local officials (Schammann 2015, p. 168 et seq.), and Täubig argues that the highly regulated and repressive everyday living conditions of asylum seekers and refugees are designed to inhibit quick integration rather than to support it (Täubig 2009). The complication of access to higher education can be one example for that. Especially during study preparations, different and even 
contradicting regulations and unclear responsibilities can lead to difficulties for prospective refugee students. For example, meeting the requirements for social benefit can contradict or prevent the visit of preparatory classes. A member of the international office at university $\mathrm{E}$ describes a case when several members of a family had to drop out study preparations in order to take part in a job-creation program:

I experienced it once with a whole family that somebody really worked against it. So he, I fought a long time for him to be allowed to take the German class, and fought long for the wife to also be allowed to take the German class. They all had to sto, because the job-centre or the consultant did completely not support it. It simply could not be. They absolutely had to take part in a job-creation program.

(Interview international office member, University E, translated by JB)

\section{Finances}

Depending on the level of income in the country of origin, the family background and potential scholarships, finances can be a serious difficulty for international students, despite the comparatively low study costs in Germany (Morris-Lange 2017: 23). For asylum seekers and refugees, finances can be a crucial hindrance. Especially during the preparatory classes, they depend on benefits under the "Asylum-seekers Benefit Act" or "Unemployment Benefit II" (ALG II) (Study In n. y.b). Depending on the length of their stay and their residential status, refugees can be supported by student loans granted under Germany's Federal Education Assistance Act (BAföG) while studying, which in one interview is described as an advantage of refugees in comparison to other international students. The application requires a confirmation of admission to a HEI and can be a high bureaucratic obstacle even for national students (Morris-Lange 2017, p. 12; also see Schammann and Younso 2016, pp. 12-13). Even though a lot of the programs universities offer for refugees are for free or financially supported, especially the time of study preparations is precarious up to impossible; while official responsibilities for financial support are unclear.

The BAföG-office says, it is the job-centres' responsibility to pay during the hold-up time, and the job-centre says, nah, we don't, because it is supposed to be supported by BaföG.

(Interview international office member, University E, translated by JB).

\section{Entrance Qualification and Missing Documents}

While $32 \%$ of refugees hold a secondary school degree with a university entrance qualification which, according to the IAB, is in most cases likely to be acknowledged as such (Brücker et al. 2016, p. 5), as for all prospective international students, the non-recognition of foreign degrees can be a serious obstacle. In 2012, 
$18 \%$ of all international students had to visit a preparatory college, because their qualification was not recognised as university entrance qualification (Apolinarski and Poskowsky 2013, p. 5). For refugees, there are some additional hindrances to be considered, an example for some cases is incomplete paperwork due to the circumstances of migration. A special case is the students from Eritrea, where a lot of people go to school, but only get a certificate after finishing their military service (ibd., p. 6). Also, especially in areas of armed conflict, a lot of refugees dropped out of school without finishing it. In case a certificate or diploma is missing, the residential status becomes important. Based on a decision of the German ministers of Education and the Arts, refugees can be given several options to still apply for higher education in case their documents are missing due to the circumstances of forced migration. The possibilities range from suitability tests to declaration on oath, and vary not only in between German states but also between single universities (Study In n.y.c).

\section{Gap in Educational Biography}

Another challenge for refugees is the gap in their educational biography. It can be assumed that it took them some time to arrive in Germany, and then it takes time to meet the criteria for applying and enrolling at HEIs. At the time they are able to start preparatory colleges or apply for higher education, they might have been outside educational institutions for years. That adds up to cultural differences of learning and language barriers. Because of the time needed for study-preparation, the interview-partners argue that the numbers of applicants with the experience of forced migration will increase heavily soon, since the people that arrived in 2015 and 2016 will soon meet the formal criteria and language proficiency to enrol.

\section{Study Culture}

Studies show that typical elements of higher education differ internationally. According to the members of the HEI, mode of discussion, self-discipline etc. can be issues for international students and refugees who have been socialised in different learning environments. Getting accustomed to a new study culture can take time and hard work, especially after some time completely outside of educational institutions (Morris-Lange 2017, p. 22). When asked about specific challenges for refugees that want to access higher education, five of the eight interview-partners described teaching and learning styles and different organisation structures of HEIs as crucial issues.

That group work is rather unknown. That "chalk and talk" teaching is preferred.

(Interview first contact, University D, translated by JB)

As a solution, they proposed social integration and intense counselling. 


\section{Social Isolation}

Many international students state that they would like to have contact with national students but find it difficult (Apolinarski and Poskowsky 2013, p. 48). Since their support networks are mostly abroad, they need that contact for personal reasons but, most likely, also to help them get along in German higher education institutions (Morris-Lange 2017, p. 25). One interview-partner also mentioned this network when it comes to getting internship-positions. Throughout the interview, contact with peers is argued to be an important factor for social integration and therefore academic integration in Germany.

Actually, the biggest win is that they finally meet Germans at the same age. Which is great and to me an example of really successful integration, because at some point this, this factor, is somebody a refugee or not, it does not matter at some point, because it is simply, yes, contact to peers.

(Interview first contact, UAS B, translated by JB)

Based on this, the interview-partners argue to teach international students with and without the experience of forced migration together as soon as possible and quickly integrate refugees in regular classes.

\section{Information}

The availability and utilisation of consultation and support vary in connection to the local network and available information. As the first contacts describe it, for many refugees, personal interactions seem to be more important than information on the websites (see Baker et al. 2017).

They generally look for information. So the self-information is not very strong. Many want information from face to face interaction, instead of looking it up at the internet first, as I would do it.

(Interview first contact University D, translated by JB)

Generally, international students make use of information centres more often than national students (Ebert and Heublein 2017). For refugees, counselling is especially important and also difficult because of the already mentioned involvement of many actors and regulations: "The plurality of actors involved and complexity of legislation furthermore make it difficult for refugees to quickly get the information they require, and to understand it correctly" (Levantino 2016, p. 90). Especially during the interview with first contacts, the need of valid information was constantly emphasised and it was criticised that information gained via a personal network can be misleading, but also that incorrect information was given to the refugees from other institutions.

Many refugees that come to me daily have been given wrong information. [...] For example from friends, acquaintances, the job-centre.

(Interview first contact UAS A, translated by JB) 


\section{Residential Status}

More than two thirds of international students come from countries outside the European Union and need a residence permit in order to stay in Germany which needs to be renewed frequently. Academic success and finances have an impact on the renewal process. Even for successful students, this process can mean a lot of stress and put additional pressure on them and their studies (Morris-Lange 2017, p. 24). Nonetheless, the specific situation of refugees generally seems to be more insecure. Processing times in the Asylum procedure can be months, but can also last over a year (Brands and Morris-Lange 2016), and it is unclear if study success influences the procedure at all. Long waiting periods accompanied by the fear of deportation can cause high "psychological cost of uncertainty awaiting the outcome of the recognition process" (Levantino 2016, p. 90).

\section{Residence Obligation and Infrastructure}

The (in)ability to choose their place of living and their freedom of movement inside the country can be an important factor for refugees. Especially during the first months, they are under residence obligations and not able to choose their place of living. Even after that, preparatory classes are only available at certain locations, so if refugees are able to participate depends on where and how well connected they live. In relation to the cooperation with other relevant institutions, as the job-centres, one interview-partner mentions that it was much easier to work with the one in the university's city than with job-centres in the region. Two interview-partners mentioned the financing of public transportation tickets as a crucial hindrance for some prospective students.

But it is very difficult that the refugees pay for the ticket to the free language class themselves. Not all of them can do that.

(Interview first contact UAS A, translated by JB)

\section{Trauma and Psychological Stress}

Having to flee a conflict zone, potentially leaving family and friends behind, living in a new country under restricted conditions and never knowing how long one is able to stay-all interview-partners mention the insecure living conditions and past and present trauma as a huge challenge for refugees; they are at least a constant distraction up to a major influence on productivity and aspirations. Most HEIs do not offer specific psychological counselling for traumatised people. While on the one hand, refugees can use the HEIs' general psychological counselling, the vice-president for internationalisation at UAS A refers to the responsibility of the whole society which points at the fact that the integration of refugees into higher education does not only depend on the support they receive from preparatory colleges and HEIs. 
When we have many traumatised people in the country, then it is actually a task of the country to take care of it. And I do think it has to be taken care of, but I don't know if it is the university's task.

(Interview vice-president for internationalisation, UAS A, translated by JB)

\begin{abstract}
Absence
Three interview-partners describe absence from preparatory classes as a central issue. They explain it with other responsibilities within the multitude of bureaucratic requirements, family issues, a lack of motivation caused by trauma, the need to work due to financial issues and religious reasons for absence during Ramadan. This shows how challenges on several levels manifest as an influence on study success.
\end{abstract}

If a family member is doing badly, they sometimes stay at home. Because at this moment one has to take care of the family, not of the German class.

(Interview first contact, University D, translated by JB)

\title{
Support Structures at German HEI
}

In order to help refugees to deal with the previously described challenges, many German HEIs institutionalised different support structures and offers. The sample shows some differences in the specific offers; within the path dependency of pre-existing organisational structures, some of the specific offers of the sampled HEIs include strong collaboration with local businesses, specific offers for traumatised students or extensive online-classes. What all sampled HEIs have in common are language classes, academic preparation like math-courses, offers to support the social integration and the offer of access to infrastructure like libraries and Wi-Fi for refugees. Hereafter, the HEIs will be shortly described, and an overview of their specific support for refugees will be given.

University of Applied Sciences (UAS) A is focused on the combination of theory and praxis with praxis-oriented teaching and on internationally oriented research. Internationalisation is a crucial part in the UAS mission statement and broadly promoted in order to support students' career opportunities and extend research possibilities in a globalised world and market. Therefore, the position of a vice-president for internationalisation has newly been implemented and online-courses, international study-programs, exchange programs, partnerships and international research cooperation are maintained and extended. The UAS A is well appointed with funds and staff: While the Universities of Applied Sciences A and B have about the same number of students, there are 532 enrolled students per person working at the international office, 182 less than at UAS B. 
Within the international office, a position for the counselling of refugees has been established in November 2016. Because there is no nearby preparatory college available, the UAS offers a three stages study preparations program, including counselling, language classes and academic preparation. The program is supported by local companies, which offer funding. Further offerings are social events, (already existing) international study programs in English and online classes. The information on the website is addressed to prospective refugee students. While there is broad support and even funding offered, the online information for refugees is only available in German. This HEI is the only one in the sample that offers applying refugees to benefit them by raising their entrance qualification grades during the application process.

University of Applied Sciences B is practice-oriented and works closely together with relevant companies. In the University of Applied Science's Profile, student mobility is described as a crucial part in supporting the career opportunities for local students. The international office mostly focuses on student mobility, mainly via exchange programs and international study programs. There are 714 enrolled students per person working at the international office. A position of a vice-president for internationalisation and a mission statement for internationalisation have not been established yet, but within the international office, there is a department for the support of the internationalisation process and of social inclusion for international students.

Within this department, the engagement for refugees is coordinated. This was initially done within the regular working hours and partly as voluntary work. Starting with September 2017, a 20\% position for the consultation of refugees was established. Even though there was no institutionalised position to do it, due to a lot of voluntary activities, the UAS B started a supporting program in 2015. The three stage program includes counselling, language and academic courses and support for social integration. The UAS B has its own preparatory college. In addition to this and in cooperation with the local university, audits, trips and other social events, access to the library and Wi-Fi and information on studying and applying are offered. Detailed information and related links are provided on the website in German and English. They are addressed to prospective refugee students and to already enrolled students who want to support refugees. Special about this HEI is a program that allows enrolled students to do an intercultural training and collect credit in exchange for their support of refugees. In an interview, the first contact for refugees explained that this way the voluntary engagement should be acknowledged and maintained after the topic is not present in the media anymore.

University (U) $\mathbf{C}$ is a university of excellence with a profile of high-quality research and a strong orientation towards internationalisation and diversity. The mission statement for internationalisation includes the mobility of students and academic staff, as well as research-cooperation and the internationalisation of teaching, including international study-programs. It explicitly emphasises service for all international incomings beyond academic questions, and a comprehensive approach. Internationalisation is meant to attract the best researchers and students and not only understood as the international office's task, but as a mission of the 
entire organisation. Per person working at the international office, the university has 571 enrolled students.

The support for refugees is located at the university's centre for diversity, where a 50\% position has been established as a first contact and counsellor for refugees. This allocation is different to the other HEIs, where support for refugees is mostly located within the international office. That can be explained with a focus on the special needs of refugees and also with a generally stronger involvement of the centre for diversity with international students. Information for refugees on the website are available in German and mostly also in English; they address prospective students as well as academics with the experience of forced migration. Most information is about the university counselling and support offers and the criteria to apply and enrol. Support programs for refugees at university $\mathrm{C}$ include language classes, audits, infrastructure (access to premises, the library and Wi-Fi), a buddy-program and students initiatives like a refugee law clinic. The first contact for refugees explains in the interview that most of the service for refugee and asylum-seeking prospective students is included in services that already existed and are now extended. Newly implanted offers are the counselling service and language classes. They started in 2015. A special offer that is embedded in the already existing institutional structures is psychological counselling for people with trauma.

University $\mathbf{D}$ is one of the leading Technical Universities in Germany. Within its extensive internationalisation mission statement, the focus is on student mobility and exchange, additional points are networking, research cooperation, researcher's mobility and the support of a north-south dialogue. Cooperation and aims to win new international students are targeted at certain countries. The head of the international office explains this regional focus with historically grown structures. Within the sample, the international office has about half the staff compared to University $\mathrm{E}$ and also less international office employees but more than double as many students as University C. There are 1627 enrolled students for every person working at the international office.

Within the international office, a 50\% position has been established to counsel refugees and administrate special offers for them. The university's homepage offers information for prospective students, mostly on entrance criteria, preparatory courses and colleges, relevant institutions and offers at the university and finances. For researchers with a refugee background, contact information is given in order to support connection and access to the university. All information is given in English. In addition to academic and language preparation and the regular offers of the international office and student counselling, a buddy program and students volunteer projects offer social inclusion and a refugee law clinic.

University $\mathbf{E}$ is the biggest university in the sample; it is almost two and a half times as large as University C. While it does have a strong focus on internationalisation in its mission statement, no position of a vice-president for internationalisation has been established yet. Internationalisation includes research cooperation, student and staff mobility and international study programs and is strongly seen in connection with a globalised market. Per person working at the international office, there are 982 enrolled students. 
Within the international office, a $50 \%$ position for the counselling and the coordination of support-offerings for refugees was established in April 2017. Before that, it was done in addition to the regular work by another member of the international office. The person the university lists as a first contact for refugees is a volunteering emeritus professor, who also offers counselling for refugees. The university's homepage offers detailed information on formal criteria for application and enrolment, missing documents, language classes and preparatory courses for prospective refugee students and academics with the experience of forced migration, in German and English; central information is also available in Arabic, Sorani and Kurmanji. Compared to most other HEIs, the extensive information available on the website for refugee and asylum-seeking academics is remarkable. The university supports refugees with German classes, audits, counselling and library-access and offers cooperation and networking for academics with a refugee background.

\section{Conclusion}

All sampled HEIs did not have special offers for refugees before 2015, which shows how closely the HEIs are connected to the topics of society. It can be understood as part of their "Reflexivität" (self-reflexivity) (Weinbach 2008, p. 183), which means that HEIs as organisations reflect on their environment and react to changes as they are currently trying to find ways to include refugees in their system of higher education. Generally, this reflectivity results in special offers to prepare refugees. Many HEI members describe helping to integrate and educate refugees as one of the HEI's contributions to society, while also they expect support and integration programs from society, the government and other actors. How far they can support refugees depends on funding, individual engagement and also on previously existing structures. For example, the only university in the sample that offers special counselling for traumatised people did already work on that topic before. For some questions, the HEI's international office and counselling staff are just not qualified, so other structures are necessary.

Of course sometimes people come, who are in the middle of legal actions because [...] they got a negative notification. Then we say, okay, there is a refugee law clinic or a lawyer must be asked, but we can't do this, also counsel on legal questions of asylum

(Interview first contact University $\mathrm{C}$, translated by JB)

After 2015, even HEIs with small international offices set up broad support structures. A lot of them started out as volunteer work and then were institutionalised; at UAS B even the student support initiatives became a part of the "Studium Generale" and can be rewarded with credit points. When the interviews took place in summer 2017, all sampled HEI either already had established or were establishing part-time positions for people in charge of counselling refugees and administrate support structures and courses. This is made possible by the "Integra"- 
program of the German Academic Exchange Service (DAAD), funded by the Federal Ministry of Education and Research. In most interviews, money was emphasised as a crucial factor in order to be able to guarantee the support. While generally, the first contacts for refugees maintained connections to other people in similar positions, the need for a network to exchange ideas and experiences was mentioned several times.

Within their mission statements on internationalisation, most HEIs focus on student mobility, more or less in accordance with the academic staff's mobility and academic exchange. Different actors at the HEIs work on different aspects of the process of internationalisation: academic exchange and international research projects are usually in the area of responsibility of individual academics or departments, student mobility and service for internationals is a huge part of the international offices work, while presidents and vice-presidents for internationalisation focus on strategic cooperation and transfer of organisational structures. The support-offerings for refugees are usually also facilitated by many institutions throughout the HEIS, such as language centres, student counselling, centres for diversity and student initiatives. Their coordination is mostly located within the international office, but partly also in diversity centres.

Whether and to what extent refugees are understood as part of the HEI's internationalisation or otherwise, for example its diversification, as part of a third mission etc. will need further investigation, but in the interview, they generally seemed to be understood as prospective students with special needs. Most interview-partners mention the social and academic inclusion of refugees and eventually their transformation to the status of (regular) international students as highly important. Several challenges to refugees' inclusion in the HEI are emphasised by the HEI actors, and for some of them, solutions are proposed. The integration of refugees into higher education is seen as a chance for refugees to improve their living conditions and help a quicker integration. Generally, all interview-partners assume that the number of refugees applying for higher education will keep rising.

The similar challenges that are described from the experience of different actors at 5 HEIs in 4 different German states suggest that structural support for refugees on their way to higher education is necessary; so are efforts to help social integration. The aim should be to minimize disadvantages. While the different challenges can be understood as interdepend intersections, their exact occurrence and impact depend largely on the individual situation. They cannot all be addressed by just one institution, but refugees rather depend on the support by several actors and institutions, individually addressing the numerous challenges they face. This also means that refugees can be included in pre-existing support structures, and newly implemented offerings can, on long term, be of help for other groups (partly) facing similar challenges.

The support structures include several parts of the HEI, but also actors and institutions outside of higher education. Since language skills and entrance qualification are the most direct influence on compatibility with the HEI, all sampled HEI offer courses in this context. Within their path dependency of already existing 
structures, they organize additional offers to meet other challenges. In order to include refugees, as many of the named factors as possible should be addressed by HEIs and surrounding organisations. Especially the extension of pre-existing structures, the provision of extensive and detailed information, the interconnection of support structures within and outside of HEI and the possibility of individual solutions seem crucial in order to support (not only) refugees on their way to German HEIs. Additionally, HEIs should reflect on some of their organisational structures, like their language requirements, the non-acknowledgement of some integration-courses refugees have to visit and other bureaucratic challenges they create for refugees. For example, some access criteria might need to be revised in order to comply with the situation of refugees in Germany. This would mean to take the organisational Reflexivität one step further and adjust organisational structures in order to enable the integration of a new group of students into the system of higher education.

The internationalisation of higher education, as described in the corresponding mission statements, is usually focused on program- and network-based partnerships and mobility and aims at winning high-income, highly trained students from specific areas. It mostly is a process that is pushed by and takes place within international competition. In this context, it seems obstructive to focus on refugees solely as people with special needs. Regarding the aim of the HEI members to see refugees become regular international students, it would make sense to frame them as a potential enrichment of a diverse and international HEI, but also as potential highly educated international students. This could also mean to re-think the connection between internationalisation and diversification of HEIs, and maybe shift the competitive focus of internationalisation-strategies. Structures that are implemented to support refugees can then be seen as a positive influence on the entire organisation since the support structures enrich a diverse internationalisation and might also be of use for other students on a long-term (see Schammann and Younso 2016, p. 46). Therefore, the investment in support for refugees can be seen as a general effort towards a social and diverse system of higher education.

As a bottom line, the following points should be taken into consideration for higher education policy:

- The HEIs support of refugees depends on funding. Since finances are important to refugees as well as universities, the institutionalisation of support structures like counselling and special offers for refugees as well as the funding of refugees costs of living should be supported as much as possible.

- Most HEIs started their programs with volunteer work based on a try and error strategy. A strong network and guidelines concerning regulations and demands of other institutions can be a lot of help for them.

- While the HEI do an important job for integrating refugees, they cannot do it on their own. Integration and information for refugees should be treated as general tasks of the whole society. HEIs and actors outside of higher education should be encouraged to network and cooperate as much as possible. 
- The information on the possibilities of studies for refugees should be pointed out to other relevant actors active in counselling refugees.

- Diversity and internationalisation should be framed as positive factors within a globalised world, and refugees should be seen as prospective highly capable students instead of exclusively focussing on their special needs.

\section{References}

Anerkennung in Deutschland. (n.y). Anerkennung in Deutschland. Retrieved from https://www. anerkennung-in-deutschland.de/html/de/anerkennung_im_schulbereich.php.

Apolinarski, B., \& Poskowsky, J. (2013). Ausländische Studierende in Deutschland 2012. Ergebnisse der 20. Sozialerhebung des Deutschen Studentenwerks durchgeführt vom Deutschen Zentrum für Hochschul- und Wissenschaftsforschung (DZHW). Hannover: DZHW.

Baker, S., Ramsay, G., Irwin, E., \& Miles, L. (2017). 'Hot', 'Cold' and 'Warm' supports: Towards theorising where refugee students go for assistance at university. Teaching in Higher Education. https://doi.org/10.1080/13562517.2017.1332028.

Beigang, S., \& von Blumenthal, J. (2016). Institutionelle Anpassungsfähigkeit von Hochschulen. Erste Ergebnisse einer Befragung unter allen deutschen Hochschulen bezüglich der Integration von Geflüchteten in ein Studium. Retrieved from https://www.bim.hu-berlin.de/ media/Pr\%C3\%A4sentation_HochschulenUndGefl\%C3\%BCchtete_BIM_23112016.pdf.

BMBF. (n.y.). Die Exzellenzinitiative stärkt die universitäre Spitzenforschung. Retrieved from https://www.bmbf.de/de/die-exzellenzinitiative-staerkt-die-universitaere-spitzenforschung1638.html.

Bogner, A., Littig, B., \& Mez, W. (2002). Das Experteninterview. Theorie, Methode, Anwendung. Opladen: Leske + Budrich.

Brands, F., \& Morris-Lange, S. (2016). German universities open doors to refugees: Access barriers Remain. International Higher Education, 84, 11-12.

Brücker, H., Rother, N., \& Schupp, J. (2016). IAB-BAMF-SOEP-Befragung von Geflüchteten Flucht, Ankunft in Deutschland und erste Schritte der Integration. IAB-Kurzbericht, 24.

Columbia. (n.y.). Forced migration learning module - definitions. Retrieved from http://www. columbia.edu/itc/hs/pubhealth/modules/forcedMigration/definitions.html.

Ebert, J., \& Heublein, U. (2017). Ursachen des Studienabbruchs bei Studierenden mit Migrationshintergrund. Eine vergleichende Untersuchung der Ursachen und Motive des Studienabbrichs bei Studierenden mit und ohne Migrationshintergrund auf Basis der Befragung der Exmatrikulierten des Somme. Hannover: DZHW. Retrieved from http://www. dzhw.eu/pdf/21/bericht_mercator.pdf.

Fortin, N., Lemieux, T., \& Torres, J. (2016). Foreign human capital and the earnings gap between immigrants and Canadian-born workers. Labour Economics, 41, 104-119.

Fourier, K., Kracht, J., Latsch, K., Heubleib, U., \& Schneider, C. (2017). Integration von Flüchtlingen an deutschen Hochschulen. Erkenntnisse aus den Hochschulprogrammen für Flüchtlinge. Bonn, Hannover: DAAD/DZHW.

Harris, V., \& Marlowe, J. (2011). Hard yards and high hopes: The educational challenges of African refugee university students in Australia. International Journal of Teaching and Learning in Higher Education, 23, 186-196.

Hobsig, E. (2004). Frauen auf der Flucht: Asyl und Integration in Österreich aus frauenspezifischer Perspektive. L'Homme Z.F.G, 15(2), 233-248.

Joyce, A., et al. (2010). The experiences of students from refugee backgrounds at universities in Australia: Reflections on the social, emotional and practical challenges. Journal of Refugee Studies, 23, 82-97. 
Kruse, J. (2015). Qualitative Interviewforschung. Ein integrativer Ansatz. Weinheim, Basel: Beltz Juventa.

Levantino, A. (2016). Refugees' higher education access in Germany and Italy: Different contexts, similar challenges? NORRAG News 53, Volume Refugees, displaced persons and education: New challenges for development and policy.

Morris-Lange, S. (2017). Allein durch den Hochschuldschungel. Hürden zum Studienerfolg für internationale Studierende und Studierende mit Migrationshintergrund. Berlin.

Müller, M. (2011). Intersektionalität und Interdependenz. Soziologische, Revue, 34, 298-309.

Schammann, H. (2015). Wenn Variationen den Alltag bestimmen. Unterschiede lokaler Politikgestaltung in der Leistungsgewährung für Asylsuchende. Zeitschrift für vergleichende Politikwissenschaft.

Schammann, H., \& Younso, C. (2016). Studium nach der Flucht? Angebote deutscher Hochschulen für Studieninteressierte mit Fluchterfahrung. Empirische Befunde und Handlungsempfehlungen. Hildesheim: Universitätsverlag.

Stevenson, J., \& Willott, J. (2007). The aspiration and access to higher education of teenage refugees in the UK. Compare, 37(5), 671-687. https://doi.org/10.1080/03057920701582624.

Studienkolleg Hannover. (n.y.). Studienkolleg Hannover. Retrieved March 27, 2017, from https:// www.stk.uni-hannover.de/133.html.

Studienkollegs.de. (n.y.). Studienkollegs.de. Retrieved from http://www.studienkollegs.de/ Willkommen.html.

Study In. (n.y.a). Study In: Fehlende oder unvollständige Unterlagen. Retrieved from https://www. study-in.de/de/refugees/studieren/voraussetzungen/fehlende-oder-unvollstaendige-unterlagen_ 39087.php.

Study In. (n.y.b). Study-In: Finanzierung und Finanzielle Unterstützung. Retrieved from https:// www.study-in.de/de/refugees/studieren/finanzierung-und-finanzielle-unterstuetzung_38515. php.

Study In. (n.y.c). Study-In: Voraussetzungen. Retrieved July 11, 2017 from https://www.study-in. de/fluechtlinge/studieren/voraussetzungen/.

Täubig, V. (2009). Totale Institution Asyl. Empirische Befunde zu alltäglichen Lebensführungen in der organisierten Desintegration. Weinheim, München: Juventa.

Weinbach, C. (2008). Intersektionalität'. Ein Paradigma zur Erfassung sozialer Ungleichheitsverhältnisse. In C. Klinger \& A. Knapp (Eds.), ÜberKreuzungen. Fremdheit, Ungleichheit, Differenz (pp. 171-193). Münster.

Open Access This chapter is licensed under the terms of the Creative Commons Attribution 4.0 International License (http://creativecommons.org/licenses/by/4.0/), which permits use, sharing, adaptation, distribution and reproduction in any medium or format, as long as you give appropriate credit to the original author(s) and the source, provide a link to the Creative Commons license and indicate if changes were made.

The images or other third party material in this chapter are included in the chapter's Creative Commons license, unless indicated otherwise in a credit line to the material. If material is not included in the chapter's Creative Commons license and your intended use is not permitted by statutory regulation or exceeds the permitted use, you will need to obtain permission directly from the copyright holder. 